\title{
Long-term control of central nervous system leukaemia
}

\author{
MOIRA A. GRIBBIN, R. M. HARDISTY, AND JUDITH M. CHESSELLS \\ From the Department of Haematology, The Hospital for Sick Children, London
}

SUMMARY Seventy-four children with acute lymphoblastic leukaemia had one or more episodes of central nervous system (CNS) leukaemia. 5 children had CNS involvement at diagnosis; 4 survived for less than one year. In 35 children who had not had a previous bone marrow relapse on treatment and who received combination chemotherapy, the median duration of haematological remission from the time of first CNS relapse was almost 3 years. 5 children received full dose ( 2400 rads) craniospinal irradiation after their first CNS relapse; 4 have remained in CNS and haematological remission for $2 \frac{1}{2}$ years or more. 18 children who had a CNS relapse after irradiation received 4weekly intrathecal methotrexate; in 8 children this was given via an intraventricular reservoir. The median duration of CNS remission in children receiving intrathecal methotrexate was 2 years. Systemic and intrathecal treatment was stopped in 7 children after $2 \frac{1}{2}$ years in continuous remission and in 2 children after 2 years. 4 of these 9 children remain in remission at intervals from 41 to 69 weeks off treatment but one is severely retarded. These results show that CNS disease is compatible with prolonged survival, but illustrate the difficulties of eradicating established CNS leukaemia.

Despite the introduction of routine central nervous system (CNS) prophylaxis in children with acute lymphoblastic leukaemia (ALL), overt CNS leukaemia still occurs in $5-10 \%$ of children at some stage of their disease. The best method of controlling, and possibly even eradicating, this complication remains uncertain. We here report our experience in management of CNS leukaemia during a $6 \frac{1}{2}$-year period.

\section{Patients and methods}

Between 1 January 1970 and 30 June 1976, 74 children with ALL attending the leukaemia clinic at The Hospital for Sick Children, had one or more episodes of CNS leukaemia, diagnosed by the presence of blast cells in a cytocentrifuged sample of cerebrospinal fluid. The patients were divided into five categories according to their haematological status and chemotherapy schedules (Table 1). Patients in group $V$ were seen in the early period of the study, before the use of systemic combination chemotherapy, and are therefore not further considered.

This report is largely concerned with the 37 children in groups I and II. In 35 of these CNS relapse terminated the first remission; in the other 2 children,

Received 12 January 1977 marrow relapse had followed cessation of chemotherapy on the MRC Concord trial (Medical Research Council, 1971), and the subsequent remission was terminated by CNS relapse. In these children, none of whom had had a marrow relapse while on treatment, eradication of CNS disease may be feasible.

Systemic chemotherapy. The details of systemic chemotherapy are given in Table 1. Children in groups I and II were treated with MRC protocols UKALL I (Medical Research Council, 1973) and UKALL II (Medical Research Council, 1976), or with PACS (combination chemotherapy with 6mercaptopurine and methotrexate, with periodic reinductions with prednisolone and cytosine arabinoside). In 4 of the 30 children in group I, CNS relapse followed cessation of chemotherapy after 3 years' continuous complete remission. 2 other children had simultaneous marrow and CNS relapse after premature cessation of chemotherapy.

All children in group II had received CNS prophylaxis as soon as remission was achieved. Prophylaxis had consisted of cranial irradiation 2400 rads in all children, with 2400 rads spinal irradiation in 4 children and concurrent intrathecal methotrexate (MTX) but no spinal irradiation in 3. 
Table 1 CNS leukaemia 1970-1976

\begin{tabular}{|c|c|c|c|c|c|c|}
\hline $\begin{array}{l}\text { Group } \\
\text { no. }\end{array}$ & $\begin{array}{l}\text { CNS } \\
\text { prophylaxis }\end{array}$ & $\begin{array}{l}\text { Time of } \\
\text { onset of CNS } \\
\text { leukaemia }\end{array}$ & Chemotherapy & & $\begin{array}{l}\text { Previous } \\
\text { haematological } \\
\text { relapse on } \\
\text { treatment }\end{array}$ & $\begin{array}{l}\text { Total } \\
(n=74)\end{array}$ \\
\hline $\mathbf{I}$ & - & $\begin{array}{l}\text { 1st haematological } \\
\text { remission } \\
\text { 2nd haematological } \\
\text { remission } \\
\begin{array}{l}\text { Simultaneous } \\
\text { haematological + }\end{array} \\
\text { CNS relapse }\end{array}$ & $\begin{array}{l}\text { Combination } \\
\text { UKALL I } \\
\text { PACS }\end{array}$ & $\begin{array}{l}18 \\
12\end{array}$ & No & 30 \\
\hline II & + & $\begin{array}{l}\text { 1st haematological } \\
\text { remission }\end{array}$ & $\begin{array}{l}\text { Combination } \\
\text { UKALL II } \\
\text { PACS }\end{array}$ & $\begin{array}{l}4 \\
3\end{array}$ & No & 7 \\
\hline III & - & At diagnosis & - & & - & 5 \\
\hline IV & $\begin{array}{l}+4 \\
-1\end{array}$ & $\begin{array}{l}\text { 2nd haematological } \\
\text { remission }\end{array}$ & Combination & & Yes & 5 \\
\hline $\mathbf{V}$ & - & Various & Sequential & & Yes/no & 27 \\
\hline
\end{tabular}

*For detail of protocols see text.

$-=$ prophylaxis not given; $+=$ prophylaxis given.

The 5 children in group IV all had had CNS relapses after bone-marrow relapse while on UKALL I or subsequent protocols. 4 had received CNS prophylaxis.

After diagnosis of CNS leukaemia, systemic chemotherapy was continued as per protocol; no amendments or reinforcements were made to the chemotherapy schedule. In children who had CNS relapses while off treatment, systemic chemotherapy was restarted. It was planned to continue systemic chemotherapy for $2 \frac{1}{2}$ years from the time of CNS relapse (see below).

Treatment of CNS leukaemia. CNS leukaemia was treated by a course of 6 injections of intrathecal MTX (usual dose $10 \mathrm{mg} / \mathrm{m}^{2}$ ) given at weekly intervals. In children in groups I and II maintenance of CNS remission was then attempted in one of the following three ways.

(1) MRC meningeal trial. From 1971 to 73, patients with one or more episodes of CNS leukaemia who were still in haematological remission were entered into a trial organized for the Medical Research Council. 19 of the 30 children in group I were entered in this trial, in which patients were randomized after a course of intrathecal MTX to receive 2400 rads cranial irradiation with or without 1000 rads to the spine. The details of this trial have been reported elsewhere (Willoughby, 1976). One child reported in this trial in fact received 2400 rads to the spine in error and is included in the next group.

(2) Other radiotherapy schedules. 7 children in group I who were not in the MRC meningeal trial also received radiotherapy: in 5 children the first CNS relapse was treated with 2400 rads craniospinal irradiation, and 2 of these children received monthly intrathecal MTX as well; in 2 other children cranial irradiation ( 2400 rads) was accompanied by a course of 6 weekly doses of intrathecal MTX and was followed by subsequent intrathecal MTX every 4 weeks.

(3) Intrathecal MTX. Given as maintenance treatment to 23 children (Table 2): the 4 children men-

Table 2 Long-term intrathecal methotrexate in 23 children

\begin{tabular}{llll}
\hline & $\begin{array}{l}\text { No. of } \\
\text { patients }\end{array}$ & $\begin{array}{l}\text { No. previous CNS } \\
\text { relapses per child } \\
\text { (range) }\end{array}$ \\
\hline (1) $\quad \begin{array}{c}\text { Therapeutic irradiation for } \\
\text { the same CNS relapse }\end{array}$ & 4 & 1 \\
(2) $\begin{array}{c}\text { Therapeutic irradiation for } \\
\text { a previous CNS relapse }\end{array}$ & 13 & $2-5$ \\
(3) No previous irradiation & 1 & 6 \\
(4) Previous 'prophylactic' CNS & 5 & $1-2$ \\
\hline & irradiation & 5 & \\
\hline
\end{tabular}

tioned above, who also received radiotherapy, and 19 others who had not received radiotherapy as part of the treatment for their last CNS relapse. 12 of these 19 had relapsed from the MRC trial, one had refused radiotherapy, 1 had relapsed after 2400 rads craniospinal irradiation for a fourth episode of meningeal leukaemia, and 5 had relapsed after previous CNS 'prophylaxis'. The drug was given every 4 weeks to all children initially; the frequency of injection was subsequently decreased to 6-weekly in 3 children. 15 of the children, including the 4 who had also received radiotherapy, were treated by 
lumbar puncture; in the other 8 children treatment was given via an intraventricular reservoir inserted into the lateral ventricle of the nondominant hemisphere. In 3 of the 8 children with a reservoir, intrathecal cytosine arabinoside (Ara-c) was later substituted for MTX because of complications (see below).

\section{Results (To 30 October 1976)}

Haematological remission. Fig. 1 illustrates the duration of haematological remission from the time of first CNS relapse in 35 children in groups I and II. The 2 children with simultaneous marrow and CNS relapses are excluded; both remain in their second complete remission at 97 and 217 weeks. The

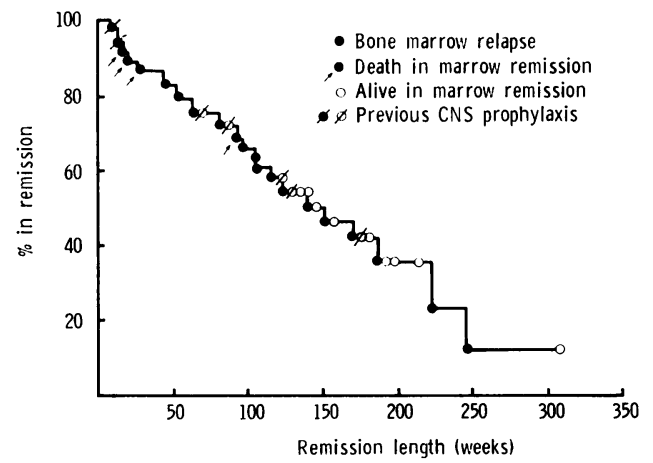

Fig. 1 Length of haematological remission after the first CNS relapse in 35 children who had not had a previous bone marrow relapse on treatment.

time from diagnosis to first CNS relapse in this group of children ranged from 19 to 188 weeks, median 71 weeks, and exceeded 2 years in one-third of the patients. Thus treatment has been very prolonged in many patients, with 19 of the 35 so far surviving more than 4 years and 12 more than 5 years from diagnosis. The median duration of haematological remission after first CNS relapse is almost 3 years but the curve shows no plateau and haematological relapses have continued to occur up to nearly 5 years from the first CNS episode.

Risk of CNS relapse after haematological relapse. Between 1970 and 1976, 206 children with ALL have remitted and received combination chemotherapy with UKALL I or subsequent protocols. To date haematological relapse on treatment has terminated the first complete remission in $\mathbf{3 3}$ of these children: 5 of the 33 children have so far had a subsequent CNS relapse.
Radiotherapy schedules. 4 of the children who received 2400 rads to the craniospinal axis for their first CNS relapse (2 of whom have also received subsequent monthly MTX) remained in complete remission at 129, 130,197, and 217 weeks from relapse. The fifth died from Pneumocystis carinii pneumonia 19 weeks after radiotherapy. The 2 children receiving maintenance MTX after cranial irradiation remained in remission at 97 and 145 weeks but one has developed encephalitis.

Long-term MTX. The duration of CNS remission in 18 of the 19 children in whom CNS remission was maintained by long-term MTX alone (Table 2, (2) $\&$ (4)) is shown in Fig. 2, where the remission

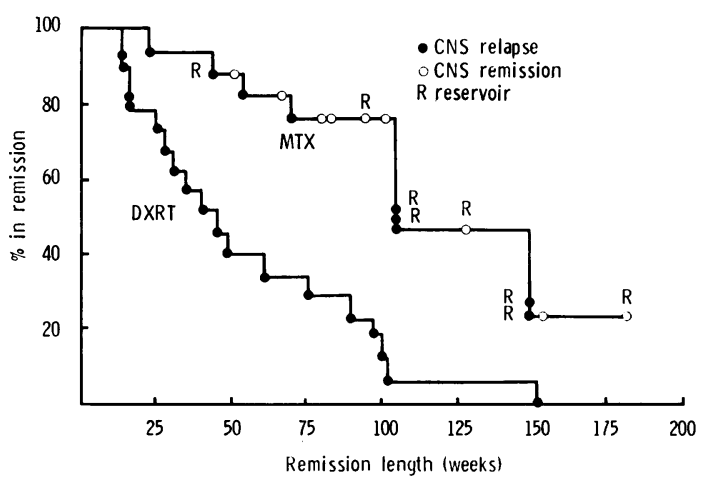

Fig. 2 Comparison of the length of CNS remission in 18 children who received irradiation $(D X R T)$ and then regular intrathecal methotrexate (MTX) for a subsequent CNS relapse. 11 children received cranial irradiation and 7 craniospinal irradiation.

duration achieved on intrathecal MTX is compared with that of the preceding remission after radiotherapy alone, whether this was therapeutic or prophylactic, and whether cranial or craniospinal. In this group of children intrathecal MTX has clearly proved more effective than radiotherapy. Duration of CNS remission on maintenance intrathecal MTX bore little relationship to the number of previous CNS episodes-one of the longest remissions occurred in a child with 5 previous CNS relapses.

The 19th child, whose parents refused radiotherapy and who had 6 previous CNS relapses (Table 2, (3)), had a CNS remission of 40 weeks on monthly MTX.

CNS involvement at diagnosis (group III). The fate of the 5 patients with CNS disease at diagnosis is shown in Table 3. Only one child survived more than one 
Table 3 CNS disease at diagnosis-group III

\begin{tabular}{|c|c|c|c|}
\hline $\begin{array}{l}\text { Case } \\
\text { no. }\end{array}$ & CNS treatment & $\begin{array}{l}\text { Systemic } \\
\text { treatment }\end{array}$ & Follow-up \\
\hline 1 & Craniospinal $24 J 0$ rads & PACS & $\begin{array}{l}\text { CNS relapse } 161 \text { weeks; died in } \\
\text { haematological relapse } 228 \text { weeks }\end{array}$ \\
\hline 2 & Cranial irradiation and methotrexate & UKALL II & Died 61 weeks; haematological relapse \\
\hline 3 & Cranial irradiation and methotrexate & Combination* & Died in haematological relapse at 35 weeks \\
\hline 4 & Craniospinal 2400 rads & Combination ${ }^{*}$ & $\begin{array}{l}\text { Died pneumonia at } 35 \text { weeks in complete } \\
\text { remission }\end{array}$ \\
\hline 5 & Craniospinal 2400 rads & Combination* & $\begin{array}{l}\text { Haematological relapse week } 12 \text {; died } \\
\text { pneumonia in remission week } 17\end{array}$ \\
\hline
\end{tabular}

*Protocols subsequent to UKALL II.

year; he remained in continuous complete remission for 3 years but cessation of treatment was followed by CNS relapse within one month, subsequent neurological deterioration, and haematological relapse.

Results of stopping treatment (Table 4). Systemic and intrathecal treatment were stopped as planned after 130 weeks in 7 patients in groups I \& II. In 2 other children treatment was stopped at 104 weeks: in Case 11 because of recurrent convulsions and Case 14 after encephalitis. 4 of these 9 children remain in remission including both of those who received full dose craniospinal irradiation and one of the 4 who received intraventricular MTX. These 3 children are in good general health with no overt neurological diability but one (who received craniospinal irradiation) is educationally subnormal. Case 14 remains in complete remission but has severe residual intellectual impairment.

Toxicity of treatment. Serious nonleukaemic neurological complications occurred in 15 of the 37 children in groups I \& II. These are listed in Table 5 and will be described in detail elsewhere (Campbell et al., 1977). The complications are grouped in Table 5 according to whether or not the patients were receiving long-term intrathecal MTX. All but one patient had been irradiated at some stage and all the children, including those not on regular MTX, had received some MTX intrathecally as well as orally.

Complications were more frequent in children with an intraventricular reservoir; only one of the 8 children with a reservoir experienced no complications and 3 children had more than one complication. 2 children developed transient hemiplegia after insertion of the reservoir, and 4 of the 8 reservoirs became infected at some stage. In 2 cases the organism was Staph. epidermidis, in one Staph. aureus, and in the fourth Acinetobacter lwoffii. All the in fections responded rapidly to antibiotics, which were given systematically in all children and via the reservoir in 3. By contrast no child at this hospital has ever developed meningitis when MTX or Ara-c was given by lumbar puncture. 2 other children in the study developed bacterial meningitis unrelated to lumbar puncture: one had meningococcal meningitis while in remission and the other developed $E$. coli meningitis while in relapse.

Fits occurred in 6 children; in 2 they were the prelude to an 'encephalopathy' (see below), and in 4 there was no residual neurological impairment. However, in 2 of the latter 4 children, both with

Table 4 Results of stopping treatment in children in groups I and II

\begin{tabular}{|c|c|c|c|c|}
\hline $\begin{array}{l}\text { Case } \\
\text { no. }\end{array}$ & $\begin{array}{l}\text { Time of CNS } \\
\text { relapses } \\
\text { (weeks from } \\
\text { diagnosis) }\end{array}$ & $\begin{array}{l}\text { Treatment for last } \\
\text { episode of CNS disease }\end{array}$ & $\begin{array}{l}\text { Course from time of } \\
\text { stopping treatment }\end{array}$ & $\begin{array}{l}\text { Total } \\
\text { survival } \\
\text { to date } \\
\text { (w) }\end{array}$ \\
\hline $\begin{array}{l}6 \\
7 \\
8\end{array}$ & $\begin{array}{r}80 \\
86 \\
104\end{array}$ & $\begin{array}{l}2400 \text { rads craniospinal } \\
2400 \text { rads craniospinal } \\
2400 \text { cranial }+1000\end{array}$ & $\begin{array}{l}\text { Well } 69 \text { weeks } \\
\text { Well } 65 \text { weeks } \\
\text { Testicular relapse } 12 \text { weeks; }\end{array}$ & $\begin{array}{l}299 \\
287\end{array}$ \\
\hline $\begin{array}{r}9 \\
10\end{array}$ & $\begin{array}{l}47,82 \\
51,78,106 \\
142,239\end{array}$ & $\begin{array}{l}\text { rads spinal } \\
\text { Reservoir MTX } \\
\text { Reservoir MTX }\end{array}$ & $\begin{array}{l}\text { haematological relapse } 37 \text { weeks } \\
\text { Well } 52 \text { weeks } \\
\text { CNS relapse } 30 \text { weeks }\end{array}$ & $\begin{array}{l}314 \\
248 \\
404\end{array}$ \\
\hline $\begin{array}{l}11^{*} \\
12 \\
13 \\
14^{*}\end{array}$ & $\begin{array}{l}46 * \\
29,60,85 \\
35,66,135 \\
171\end{array}$ & $\begin{array}{l}\text { Reservoir MTX } \\
\text { Reservoir MTX } \\
\text { Lumbar MTX } \\
2400 \text { rads cranial and } \\
\quad \text { lumbar MTX }\end{array}$ & $\begin{array}{l}\text { Testicular + CNS relapse } 12 \text { weeks } \\
\text { Haematological + CNS relapse } 18 \text { weeks } \\
\text { Haematological relapse } 18 \text { weeks } \\
\text { Haematological + CNS remission at } 41 \text { weeks; } \\
\quad \text { severe intellectual impairment }\end{array}$ & $\begin{array}{l}172 \\
275 \\
296 \\
330\end{array}$ \\
\hline
\end{tabular}

*Treatment stopped after 2 years in complete remission. 
Table 5 Neurological complications in CNS leukaemia

\begin{tabular}{|c|c|c|c|}
\hline & \multicolumn{2}{|c|}{ Regular methotrexate } & \multirow{2}{*}{$\begin{array}{l}\text { No regular } \\
\text { methotrexate } \\
n=14\end{array}$} \\
\hline & $\begin{array}{l}\text { Reservoir } \\
n=8\end{array}$ & $\begin{array}{l}\text { Lumbar puncture } \\
n=15\end{array}$ & \\
\hline $\begin{array}{l}\text { Transient } \\
\text { hemiplegia }\end{array}$ & 2 & - & - \\
\hline $\begin{array}{c}\text { Bacterial } \\
\text { infection }\end{array}$ & 4 & 1 & 1 \\
\hline $\begin{array}{l}\text { Fits } \\
\text { Intellectual }\end{array}$ & 3 & 3 & - \\
\hline $\begin{array}{l}\text { Intellectual } \\
\text { deterioration } \\
\text { Encephalopathy }\end{array}$ & 1 & $\begin{array}{l}1 \\
1\end{array}$ & $\begin{array}{l}1 \\
2\end{array}$ \\
\hline
\end{tabular}

reservoirs, fits were recurrent; in one child Ara-c was substituted for MTX and in the other treatment was stopped at 2 years. Progressive intellectual deterioration and depression were noted in 3 children, one with a reservoir and 2 who had had repeated admissions to hospital and recurrent CNS disease. In the child with a reservoir, substitution of Ara-c was followed by measurable intellectual improvement.

Four children developed neurological deterioration progressing to unconsciousness, classed as 'encephalopathy' in Table 5. In 2 children this was ascribed to MTX; one died without regaining consciousness and the other improved when MTX was discontinued but later died in haematological relapse. In Case 14 (Table 4) the encephalopathy was ascribed to measles and in the fourth child, who also died without regaining consciousness, the diagnosis remains uncertain.

Of the 3 children, all with reservoirs, in whom Ara-c was substituted for MTX, one with 'encephalopathy' died in relapse and the other 2 remain in remission at 127 weeks (73 on Ara-c) and 95 weeks (67 on Ara-c).

One child had severe disabling osteoporosis after CNS leukaemia recurred with a reservoir in situ. This responded to withdrawal of all MTX but she later died after recurrent CNS and haematological disease.

\section{Discussion}

These results illustrate the difficulties of eradicating established meningeal leukaemia and thus emphasize the importance of CNS prophylaxis in all children with ALL. Our results confirm the poor prognosis of patients with early CNS leukaemia, already emphasized by others (Aur et al., 1974).

Although the risk of haematological relapse did not appear to decrease with time in this series, the long duration of many of the haematological remissions after the first CNS relapse shows that the development of CNS leukaemia is compatible with prolonged survival, and suggests that there may be a chance of eradicating the disease in a proportion of such patients. Radiotherapy and intrathecal chemotherapy may each have a part to play in this. In the group of children in whom CNS leukaemia terminated the first remission and who had not raceived prophylaxis, the best results were achieved in those treated with full-dose craniospinal irradiation, with or without maintenance intrathecal MTX. These results are in keeping with those reported by Hustu et al. (1973) who achieved longterm CNS remission in $13 / 32$ children whose first meningeal relapse was treated by craniospinal irradiation. By contrast, Sullivan et al. (1975) found that 8-weekly MTX was superior to craniospinal irradiation 2400 rads in control of meningeal leukaemia. Details of systemic chemotherapy were not given, however, and it is not clear how many patients were in their first CNS relapse.

Irradiation of the cranium alone has proved ineffective in maintaining long-term CNS remission (Willoughby, 1976) or in producing longer remissions than those achieved by MTX alone (Duttera et al., 1973). The addition of a low dose of spinal radiotherapy has been reported to improve remission duration (Willoughby, 1976), but none of our patients so treated remain in complete remission.

The median duration of CNS remission in our patients receiving long-term MTX alone (104 weeks) compares very favourably with those reported by others: 34+ weeks (Duttera et al., 1973), 53 weeks (Sullivan et al., 1975), and 78 weeks with MTX and dexamethasone (Sackmann Muriel et al., 1976). These patients, except 4 of those relapsing after prophylaxis, had had at least two episodes of CNS leukaemia; it is conceivable that maintenance treatment after the first relapse might have been more successful.

Insertion of an intraventricular reservoir has been shown to result in more reliable CSF MTX levels than those achieved by lumbar puncture (Shapiro et al., 1975a) and has the additional advantage of allowing painless administration of the drug. However, in our hands this has been associated with a high incidence of complications. Others have found that complications become less common with greater experience (Shapiro et al., 1975b). Our 2 patients with the longest remissions so far have both had intraventricular reservoirs.

The incidence of nonleukaemic neurological complications was high in this group of children with meningeal leukaemia. These children had virtually all received cranial irradiation at some stage and had been on systemic chemotherapy for many years; the longest survivor had been treated for 7 years. They were therefore at risk from MTX-radiation 
toxicity (Kay et al., 1972; Price and Jamieson, 1975). The realization that such complications were occurring with increasing frequency was one of the factors which led to our decision to stop all treatment in children who had been $2 \frac{1}{2}$ years in complete remission. The relapse rate after stopping treatment has been disappointingly high, but 3 of the 5 children who relapsed had had three or more episodes of CNS leukaemia.

What conclusions may be drawn from this study of relevance to the management of the child who develops overt CNS leukaemia despite 'prophylactic' craniospinal irradiation or cranial irradiation plus MTX? Long-term maintenance MTX given 4weekly, possibly via an intraventricular reservoir, certainly has a role in maintenance of CNS remission; the possible benefits of additional radiotherapy, which should include a spinal component, must be weighed against the hazards of further immunosuppression, interruption of chemotherapy, and neurological deficit.

\section{References}

Aur, R. J. A., Simone, J. V., Hustu, H. O., Verzosa, M. S., and Pinkel, D. (1974). Cessation of therapy during complete remission of childhood acute lymphocytic leukemia. New England Journal of Medicine, 291, 1230-1234.

Campbell, R. H. A., Marshall, W. C., and Chessells, J. M. (1977). Neurological complications of childhood leukaemia. Archives of Disease in Childhood (in press).

Duttera, M. J., Bleyer, W. A., Pomeroy, T. C., Leventhal, C. M., and Leventhal, B. G. (1973). Irradiation, methotrexate toxicity, and the treatment of meningeal leukaemia. Lancet, 2, 703-707.

Hustu, H. O., Aur, R. J. A., Verzosa, M. S., Simone, J. V., and Pinkel, D. (1973). Prevention of central nervous system leukemia by irradiation. Cancer, 32, 585-597.

Kay, H. E. M., Knapton, P. J., O'Sullivan, J. P., Wells, D. G., Harris, R. F., Innes, E. M., Stuart, J., Schwartz, F. C. M., and Thompson, E. N. (1972). Encephalopathy in acute leukaemia associated with methotrexate therapy. Archives of Disease in Childhood, 47, 344-354.

Medical Research Council (1971). Treatment of acute lymphoblastic leukaemia: comparison of immunotherapy (BCG), intermittent methotrexate, and no therapy after a five-month intensive cytotoxic regimen (Concord Trial). British Medical Journal, 4, 189-194.

Medical Research Council (1973). Treatment of acute lymphoblastic leukaemia: effect of 'prophylactic' therapy against central nervous system leukemia. British Medical Journal, 2, 381-384.

Medical Research Council (1976). Analysis of treatment in childhood leukaemia. II. Timing and the toxicity of combined 6-mercaptopurine and methotrexate maintenance therapy. British Journal of Haematology, 33, 179-188.

Price, R. A., and Jamieson, P. A. (1975). The central nervous system in childhood leukemia. II. Subacute leukoencephalopathy. Cancer, 35, 306-318.

Sackmann Muriel, F., Schere, D., Barengols, A., EppingerHelft, M., Braier, J. L., Pavlovsky, S., Macchi, G. H., and Guman, L. (1976). Remission maintenance therapy for meningeal leukaemia: intrathecal methotrexate and dexamethasone versus intrathecal craniospinal irradiation with a radiocolloid. British Journal of Haematology, 34, 119-127.

Shapiro, W. R., Young, D. F., and Mehta, B. M. (1975a) Methotrexate: distribution in cerebrospinal fluid after intravenous, ventricular and lumbar injections. New England Journal of Medicine, 293, 161-166.

Shapiro, W. R., Young, D. F., and Posner, J. B. (1975b) Treatment of leptomeningeal neoplasm with intraventricular methotrexate (MTX) and arabinosylcytosine (ara-c). Proceedings of the American Association for Cancer Research, 16, 190.

Sullivan, M. P., Humphrey, G. B., Vietti, T. J., Haggard, M. E., and Lee, E. (1975). Superiority of conventional intrathecal methotrexate therapy with maintenance over intensive intrathecal methotrexate therapy, unmaintained, or radiotherapy (2000-2500 rads tumor dose) in treatment for meningeal leukemia. Cancer, 35, 1066-1073.

Willoughby, M. L. N. (1976). Treatment of overt meningeal leukaemia in children: results of second MRC meningeal leukaemia trial. British Medical Journal, 1, 864-867.

Correspondence to Dr. J. M. Chessells, Department of Haematology, The Hospital for Sick Children, Great Ormond Street, London WC1N 3JH. 